$20 \mid 2019$

Sedition, Sexuality, Gender, and Gender Identity in South Asia

\title{
The Transgender Nation and its Margins: The Many Lives of the Law
}

Sayan Bhattacharya

\section{(2) OpenEdition}

\section{Journals}

Electronic version

URL: http://journals.openedition.org/samaj/4930

DOI: $10.4000 /$ samaj.4930

ISSN: 1960-6060

\section{Publisher}

Association pour la recherche sur l'Asie du Sud (ARAS)

\section{Electronic reference}

Sayan Bhattacharya, "The Transgender Nation and its Margins: The Many Lives of the Law", South Asia Multidisciplinary Academic Journal [Online], 20 | 2019, Online since 18 February 2019, connection on 10 March 2021. URL: http://journals.openedition.org/samaj/4930 ; DOI: https://doi.org/10.4000/samaj. 4930

This text was automatically generated on 10 March 2021.

This work is licensed under a Creative Commons Attribution-NonCommercial-NoDerivatives 4.0 International License. 


\title{
The Transgender Nation and its Margins: The Many Lives of the Law
}

\author{
Sayan Bhattacharya
}

1 On August 12, 2015, a video was uploaded to YouTube that went viral overnight (Yathartha Pictures 2015). Uploaded by Yathartha Films, a film production house, and commissioned by Humsafar Trust, ${ }^{1}$ the video shows seven hijras singing the national anthem. We see Paras, Madhuri, Urmi, Samina, Fida, Rani and Shreya come on screen, one after the other and sometimes in pairs. While they sing the anthem, a write-up comes on the screen spelling out what alternative careers they could have had. So, for example, Paras could have been a teacher, Madhuri could have been a lawyer while Rani could have been a police officer. The viewer knows that hijras constitute one of the most marginalized communities in India. Battling stigma and multilayered forms of violence, ranging from the sexual to the physical, they are often left with no livelihood options other than begging, sex work or collecting money from families celebrating weddings or the arrival of a new born. Thus, without spelling it out explicitly, the video talks of work opportunities that have been violently foreclosed for a group of people in this country. When viewed against the backdrop of the nation's Independence Day (August 15), the violence is projected all the more starkly because here we have a group of people who have not yet had the chance to participate in the fruits of citizenship rights, that is the right to employment and a life of dignity even after seven decades of independence from British colonial rule.

2 A year earlier on April 14, 2014 the Supreme Court of India had upheld the right of Indian citizens to self-identify their gender, regardless of gender affirmation surgery in the National Legal Services Authority (henceforth NALSA) v. Union of India case. It also stated that no person can be discriminated against on the basis of gender identity. In order to ensure nondiscrimination, the Court advocated for reservations for transgender individuals in jobs and education. So then, Yathartha's video featuring hijras is not only about the rights they have been denied but also about what they can potentially achieve and aspire to, thanks to the NALSA judgment. The video was therefore a call to the government to act on the Supreme Court ruling and ensure its 
implementation. Thus, what the video effectively did was to present the stake that this much stigmatized and reviled group of people has in achieving full citizenship in the Indian nation, a message delivered, in this case, on the eve of India's Independence Day on August 15. The video is titled Bharatiya... (Indian), highlighting the fact that these people have not yet found a space within the framework of Indian citizenship. The ellipses are followed by the words, Hum bhi hain (We are also there). The two sets separated by the ellipses put together would thus read, "We are also Indian." The video was thus, a straightforward audiovisual statement that uses the trope of nationalism to advocate for the inclusion of a group of marginalized people within the discourse of citizenship.

3 This paper interrogates the terms on which such citizenship is granted to transgender individuals. Or put differently, who can have access to such citizenship rights? Does such an access also create violent exclusions, as in a group of transgender individuals who must be denied such rights? The paper is divided into three sections. The first section offers a brief summary of some of the debates happening around nationalism in India's queer and transgender communities. The Yathartha video was not the only media campaign that used the template of nationalism to advocate for transgender citizenship. There have been other campaigns as well. Most importantly, the current government which is aligned with a majoritarian Hindutva ideology has approved a Bill that is supposed to safeguard the citizenship rights of transgender individuals. Hence the imbrications of nationalism with the queer and transgender communities must be interrogated. However, I argue that any totalizing framework fails to account for the complex and multiple challenges which India's queer and transgender communities pose for nationalism. Instead, I argue for a thick description of such challenges as a way to complicate any meta-narrative about transgender citizenship in India. In the second and third sections of the paper, I offer such thick description from the site of law. I closely read The Transgender Persons (Protection of Rights) Bill, 2018 that the Government of India has recently approved and which will become law once it is passed in the parliament. This Bill was passed following the NALSA verdict and is supposed to be that one piece of legislation that will enshrine the citizenship rights of transgender individuals in India. I examine this Bill in conjunction with the Supreme Court verdict to understand how law discursively produces the transgender citizen and how India's transgender communities are reacting to such constructions. The second section focuses on the definition the Bill proposes for the category "transgender" and the ramifications that such a definition has had on representations of the transgender identity in popular media. The third section focuses on how the Bill addresses the right to work for transgender individuals, tying back to the Yathartha video, which focused on various employment opportunities that transgender individuals must have. A discourse analysis of the legal and popular representations of transgender individuals alongside reactions from India's transgender communities towards law allows me to examine the various contestations around transgender citizenship in India. Here it must be noted that for reactions from India's transgender communities, I cite both anecdotal evidence of meetings and protest marches as well as blog entries and commentary on social media written by transgender and gender non-conforming individuals in India. This is to acknowledge and pay close attention to the abundance of community-based critique generated in the aftermath of the Supreme Court ruling and the approval of the Bill by the Indian government. Taken together, the paper stages two questions: What does it mean to deploy nationalism as the pathway to citizenship 
and respectability? And, does it mean that the hijra subject can find a "home" in the nation-state only by performing nationalism?

\section{The narrative of nationalism}

4 In the light of anti-colonial struggles in India in the nineteenth century, Partha Chatterjee argues that nationalism was established in colonial society by "dividing social institutions and practices into two domains-the material and the spiritual" (Chatterjee 1993:6) The material was the outside, that is the economy, state institutions, science and technology while the spiritual was the marker of cultural identity. While Western domination in the realm of the material was accepted, it was in the domain of the inner that a cultural sovereignty was staged. Thus, national culture was that unifying historical object that produced the charge of Indian nationalism, a domain beyond the intervention of imperial governance. Even as the state was under colonial rule, the imagined community of the Indian nation was fashioned through the crafting of a national culture that was to be distinct from any Western influence. This culture could be in the form of vernacular literature, distinctive from the influence of English as a colonial language or the status of women in the middle-class, upper caste household, among other examples. This active crafting of a national culture could perhaps be connected to Sudipta Kaviraj's theorization of the narrative contract in relation to the imaginaries of the Indian nation. Kaviraj argues that narratives are used to impose stability on groups of people and to unify them. However, narratives are not universalizing discourses. They are not for all to hear or to participate in. Kaviraj (1992) writes, "the recipient of the narrative cannot be just anybody: it is only some people belonging to particular categories who are privileged by the narration" (p. 37). Kaviraj gives the example of writer and visual artist Abanindranath Tagore's illustrated folktales to show how the intended audience of these tales could never be Muslim children because the Muslim was always constructed as an outsider to a national culture that was always already Hindu. Thus, the spiritual sanctity or the national culture of the nation is produced through narratives that extend the ideology of nationalism, which can only be accessed by some and not others. For Kaviraj, narrative is both storytelling as well as the connecting links between events. However, these connecting links are about selecting objects that clearly mark those connections. Some other selections could set off disjunctures and contradictions in the space between events. The realm of the inner domain, which in Chatterjee's thesis is the site of the national culture, is thus also a narrative construction, full of resistances and contestations. In fact, even though Chatterjee marks out the material and the spiritual, he also says that the divisions are not so neat. Not only do the domains put pressure on each other but they also inform each other (Chatterjee 1993:13). Narratives produce both national belonging as well as unbelonging. In this paper, I will argue that micronarratives of unbelonging continuously disrupt any meta-narrative of national belonging. We could extend these debates on nationalism to the realm of the Indian queer and transgender movements to examine how belonging and unbelonging are produced.

5 In a special issue for the Jindal Global Law Review, the editors Oishik Sircar and Dipika Jain recount the invocation of "Jai Hind" at a pride march and draw on Jasbir Puar's formulation of homonationalism to argue that this is India's homonationalist moment. 
Following Partha Chatterjee, they term this the "nationalist resolution of the homosexual question," whereby a majoritarian conception of the Indian nation as a Hindu state subsumes the so-called deviancy of the homosexual within its fold (Sircar and Jain 2013:19). In other words, homosexuality is an internal matter that does not constitute a problem for the Hindu nation. Jai Hind is not incommensurable with a pride march. Thus, homosexuals belong to the Hindu nation, the obverse of which is that Islam and homosexuality are incommensurable. Jai Hind at the pride march produces the narrative of Hindu homosexual belonging within the nation, where the Muslim homosexual cannot belong.

6 Sircar and Jain's theorization of homonationalism in the Indian context finds further credence in some recent developments surrounding Section 377 of the Indian Penal Code (1860), the colonial era law that was used to criminalize any form of sexual contact other than peno-vaginal penetration. In effect, Section 377 criminalized homosexuality in India. The Supreme Court of India finished hearing a series of petitions against the law in July, 2018 and pronounced on September 6, 2018 that consensual sex in private cannot be criminalized. However, the hearings on Section 377 that culminated in this judgment prove instructive in understanding the imbrications of Hindu nationalism and the Indian queer and transgender movements. The central government, ruled by the Hindu right-wing party, Bharatiya Janata Party (henceforth BJP) submitted to the Court that it would leave the decision on Section 377 to the court, which meant it would neither contest nor advocate for decriminalization of the law. This is indeed a shift in BJP's position on homosexuality. Svati P. Shah recounts that when Fire-a film about a lesbian relationship-was released in 1998, Shiv Sena, one of BJP's partners and part of the Hindu right, proclaimed that such films should not be allowed to be screened as it might promote lesbianism and destroy Indian families. In other words, in the 1990s, the domain of national culture did not have space for nonnormative sexualities. However, almost a decade later, BJP's stance underwent a subtle shift and it declared that homosexuality is an elite issue, symptomatic of the BharatIndia divide (Shah 2014:646). From there, BJP has now further shifted to a position in which it is not opposing the decriminalization of homosexuality. This position has caused a lot of cheer among those queer individuals and activists who are ideologically aligned with the Hindu Right because now there is no opposition between the Hindu Right and gay rights. Hence, the invocation of Jai Hind at a pride march is not incongruent any longer, as national culture is now capacious enough to take homosexuality into its fold. Against such a backdrop, Nishant Upadhyay argues that any attempt to portray Hinduism as a religion that is tolerant towards gender and sexual minorities obfuscates the violent structure of caste that is at its foundation. A religion cannot be simultaneously tolerant towards minorities and at the same time sanction caste-based violence. They continue:

Following global anti-Islamophobic homonationalist formations in the US, the UK, Israel, and elsewhere, Hindus are also mirroring these processes. This allows them to construct themselves as "modern," "progressive," and accepting of queer and trans peoples, what we can call as homohindunationalism. (Upadhyay 2018)

This forceful articulation of Hindu nationalism within queer and transgender movements can be detected in some other instances as well. In an article published on September 24, 2016, in Dainik Bhaskar, one of India's most widely circulated Hindi dailies, prominent hijra activist and mahamandaleswar (the main leader) of the Kinnar akhada, ${ }^{2}$ Laxmi Narayan Tripathi claims that transgender women have carved out their 
space in religion; it is now time for them to find their niche in the Indian army. Laxmi goes on to proudly proclaim that there should be a "kinnar battalion" that would wipe Pakistan from the face of the planet. She was responding to questions from the media, on an alleged strike by Pakistan (the Muslim other of Hindu India) on India's northern borders. While Laxmi's proclamation chimes in with the jingoist climate currently dominating India, this invocation of nationalism as a trope to claim Indian citizenship and thus legibility in the Indian polity is similar to the Yathartha video depicting hijras singing the national anthem. A similar video can also be found on the YouTube channel of the External Publicity and Public Diplomacy Division of the Ministry of External Affairs: it depicts a group of transgender women participating in a drill, preparing for the Independence Day march in Bhubaneswar, Odisha in 2016.

7 It is no coincidence that the Yathartha video was commissioned by Humsafar Trust, one of India's most renowned non-profit groups for gay and transfeminine individuals. The founder of Humsafar, Ashok Row Kavi, arguably the father of the Indian gay movement having been one of the first individuals to have come out in public in 1984, is wellknown for his Hindu right-wing politics. One of the most prominent illustrations of his politics can be found in Nivedita Menon's introduction to the Sexualities anthology published in 2007. Menon writes that when the premises of Bharosa (a partner of Naz International), a Lucknow based NGO working on HIV-AIDS were raided by the police and its employees were charged under Section 377 (Indian Penal Code 1860) and under obscenity laws in 2001, Kavi wrote an article highlighting that a Muslim of AngloBangladeshi origin (Shivananda Khan) was at the helm of Naz and that Naz was supposedly extending its activities to cities such as Chennai, which was the "capital of Dravidian sub-nationalism." Kavi has always spoken for gay assimilation within a Hindu India and has steadfastly maintained that India is tolerant of minority communities because it is a Hindu-majority state (Singh and Rampal 2018). ${ }^{3}$ The reason to highlight Kavi's politics is to underline that the visual of hijras singing the national anthem and claiming they are Bharatiya, a Sanskritic version of Indian, has a longer history in his majoritarian Hindutva politics. All these examples illustrate how Hindu nationalism is becoming a conduit to staking a claim to citizenship for queer and transgender communities in India.

8 Thus, studies of the connections between Hindu nationalism and the queer and transgender movements are important and timely indeed. However, I argue that such theorizations also betray a problem. They produce totalizing narratives about the Indian queer and transgender movements without paying closer attention to the complex ways in which the imaginary of the Hindu nation is also intensely resisted and contested by queer and transgender communities. These contestations resist any singular narrative about queer and transgender lives in India. I argue that theorizations of the imbrications between Hindu nationalism and queer and transgender movements need to be complicated by the varied ways in which the Indian state manifests itself in queer and transgender lives. Jyoti Puri (2016) argues that the state is culturally and historically produced and it relies on an "active fashioning through ideas and practices, giving it the illusion of being monolithic, coherent, rational, permanent, and irrefutably there" (p.9). Instead, she draws on Timothy Mitchell to argue that the management of sexuality and sexual labor serves to discursively produce the state and its state effects. I draw on her theorization of state effects and extend it to the realm of gender to examine the diffuse ways in which the 
state deploys law to both regulate as well as extend rights to non-normative genders, and it is through such regulation as well as rights extension that the state seeks to reproduce itself. However, such regulation also meets resistance that disrupts the stability of the state. It is in paying close attention to these regulations and their disruptions that theorizations of Hindu homonationalism can be problematized.

For instance, if we closely follow our earlier example of the Indian state headed by BJP not actively opposing the decriminalization of homosexuality, then we will observe that this is only one part of the narrative. Through its additional solicitor general Tushar Mehta, the Indian government also discouraged the Supreme Court from guaranteeing sexual orientation as a fundamental right of Indian citizens, lest such a right promote incest, bestiality and sadomasochism. It reminded the Court of the Hindu Marriage Act, which governs heterosexual marriages between Hindus and cautioned that if the court were to decide to extend marriage rights to queer people, then the government should be given adequate time to respond. Thus, what is noteworthy here is not only the state's conflation of homosexuality with sexual practices that are deemed perverse but also its anxieties about protecting the very foundation of the heteronormative state that is marriage. Marriage between heterosexual individuals leading to the birth of future citizens is what keeps the wheels of the nation-state turning, and hence even if a concession can be made for the right of sexual practices in private, such a right cannot become public, leading to same-sex marriages. The same state, headed by a Hindu right wing party that is not opposing the right to choose one's sexual partner is unwilling to expand that right to include marriage. Thus, examining the state effects of law precludes any singular narrative of the relationship between Hindu nationalism and India's queer and transgender movements.

In an essay about how globalization has informed social movements in India, Mary John argues for the need for thick description from different situated locations to understand how they disrupt so-called overarching frameworks, such as globalization or the nation (John 2009:49). In the next two sections, I draw on John's methodology and Puri's theorization of state effects to provide a thick description of how law, in this case, The Transgender Persons (Protection of Rights) Bill, 2018 constructs the transgender citizen in India and how such a construction informs popular imaginations about the transgender subject.

\section{Gender, law and the citizen}

\section{Who is the transgender subject in law?}

11 In August 2016, the Government of India approved The Transgender Persons (Protection of Rights) Bill, $2016^{4}$ that was supposed to protect the rights of transgender people in India, once passed in the Parliament. The Bill had incorporated none of the feedback given from the country-wide transgender community-led consultations when a draft version of the Bill was circulated at the beginning of 2016 for community feedback (Government of India 2015). ${ }^{5}$ In fact, the Bill was a much-watered down version of the draft circulated in January, 2016. The Bill defined "transgender" as:

(A) neither wholly female nor wholly male; or

(B) a combination of female or male; or

(C) neither female nor male; and 
whose sense of gender does not match with the gender assigned to that person at the time of birth, and includes trans-men and trans-women, persons with intersex variations and gender-queers. (Government of India 2016:2)

Thus, the State's definition of gender was rooted in the binary in which "transgender" as a category is simply a lack which needs to be pathologized. Also, by defining "transgender" as combinations of both or being neither, the State refused recognition to those trans individuals who identify themselves as simply "male" or "female." In other words, the State refused to dissociate one's gender identity from the gender assigned at birth-a definition that is, in short, biologically deterministic. A Standing Committee was constituted later in 2016 that asked for community feedback on the Bill and this body incorporated community feedback and advocated for a change in the definition. On December 17, 2018, Lok Sabha passed the Transgender Persons' (Protection of Rights) Bill, 2018 and the current version of the Bill has amended the definition of transgender:

"transgender person" means a person whose gender does not match with the gender assigned to that person at birth and includes trans-man or trans-woman (whether or not such person has undergone Sex Reassignment Surgery or hormone therapy or laser therapy or such other therapy), person with intersex variations, genderqueer and person having such socio-cultural identities as kinner, hijra, aravani and jogta. (Government of India 2018:2)

Even though the current version of the Bill makes an improvement on the definition of "transgender," it has not taken into account, community feedback on the mechanisms of gender recognition. It does not mention self-affirmation of gender which directly contradicts the 2014 verdict of the Supreme Court of India that upheld the right of all citizens to the self determination of their gender. One could identify as "male," "female" or "third gender" regardless of the gender assigned at birth. For this identification, gender affirmation surgery would not be a criterion. In fact, the current Bill explicitly contradicts the NALSA verdict by stating that transgender individuals will have to apply for a transgender certificate to the District Magistrate, who will then refer the application to a District Level Screening Committee to be constituted by the appropriate government. This committee will be comprised of:

(a) the Chief Medical officer;

(b) the District Social Welfare Officer;

(c) a Psychologist or Psychiatrist;

(d) a representative of the transgender community; and

(e) an officer of the appropriate Government to be nominated by that Government.

(Government of India 2018:3)

While the provision of the screening committee was mentioned in the 2016 version of the Bill as well, the 2018 version makes it even more complicated. While those who identify as "transgender" will have to be approved by this committee, those who identify as "male" or "female" will have to produce evidence of gender affirmation surgery. The Bill states, "such person may make an application, along with a certificate issued to that effect by the Medical Superintendent or Chief Medical Officer of the medical institution in which that person has undergone surgery..." Thus, even though the state has made a concession on the definition of transgender, in effect, its conception of gender is still rooted in the medical establishment.

These criteria raise a number of questions. On what basis is a government-constituted Board the custodian of one's sense of self? On what basis will the transgender representatives on the Board be selected? Such a screening committee could flatten out the complex lived realities of those people who do not undergo surgery but still 
identify as transgender, those who want to be referred to as simply "men" or "women" or those who do not identify with any category. How will this Board decide to whom they will give the "transgender certificate"? Also, how will the State ensure that the Board is representative of the varied caste and geographic locations of transgender people? For these specificities also closely inform one's understanding of gender and how that understanding plays out in public and private spaces. Moreover, the presence of psychiatrists on the Board despite the long history of how the clinic is often a site of pathologization of one's sense of self shows how the State refuses to go beyond the medical model of gender. For example, West Bengal, a state in eastern India, constituted a Transgender Development Board in 2015 following two consultations in which mostly non-governmental organizations from the state capital, Kolkata and its suburbs participated. Groups outside the circuits of funding from international donor bodies, located in various districts of the state were largely unrepresented in these meetings. Finally, when the names of the Board Members were announced, there was no representation of groups outside Kolkata and its suburbs. ${ }^{7}$

Beyond the immediate ramifications in terms of an affront to one's sense of self, a screening committee also has other far-reaching consequences. To understand such consequences, one needs only to look back a couple of decades. The discourse surrounding non-normative sexualities in India became charged with debates on the authenticity of identity labels in the 1990s. Shivananda Khan, the founder of Naz Foundation International, contended that the term "gay" was a Western imposition and that many men in India simply had sex with men, or with anyone of any gender without necessarily identifying as gay. For HIV prevention programs to be effective, Khan argued that the authentic way to articulate same-sex desires in India would be to use the category MSM (men who have sex with men) as opposed to gay and lesbian which were used in India only in elite circles. However, Khan's arguments are selfcontradictory, as demonstrated by Nivedita Menon (2007:16-18). Firstly, his notions of the West and authentic notions of Indian culture were essentialist. Secondly, if gay/ lesbian as identity markers are solely used in the West, then why is it that not all homosexual men and women in the West use these terms to identify themselves? Isn't MSM also an English term, coined by NGOs working on AIDS, and that would require translations into several cultural and linguistic contexts as not everyone would automatically identify as MSM? Then how is it different from gay? Identities are contingent on socio-political and historical conditions. They are relational in the sense that they derive their meaning from what they are not and their formation is a process, not frozen in time. Identities are forged through the "positive technologies of power" as well as through resistance to these mechanisms (Foucault 1975:50-52). The normalization techniques of power ensure that identity labels keep proliferating. Thus, MSM necessitates the heightened visibility of other categories such as "transgender" and "kothi" and each tries to outdo the other in embodying the so-called authentic identity that can claim funding from transnational donor bodies.

In fact, Ani Dutta and Raina Roy point out how it was only in the third phase of the National Aids Control Program (NACP) that the category "transgender" came into official circulation as yet another "high risk group" requiring attention in India. "Transgender" was used as an umbrella category that subsumed regional variations like kothi and dhurani, but at the same time it was strictly differentiated from MSM, the latter being deemed a sexual behavioral category while the former was a gender 
identity. Accordingly, AIDS funds were allocated to the transgender population, thus heightening the homo-trans binaries (Dutta and Roy 2014:327-28). These identity wars became intense in the 1990s and 2000s as more funds started flowing in for HIV-AIDS. The last few years have witnessed a steady shrinkage in funds for HIV-AIDS and so the identity wars seemed to be cooling down too. However, with the institution of screening committees and the promise of welfare, the wars around authentic transgender identities have received a new charge.

\section{The state effects of legal definition}

15 A month after we witnessed the Yathartha Films video featuring hijras singing the national anthem, another video went viral overnight before it was taken down as the result of widespread condemnation. The video uploaded on September 22, 2015 by The Logical Indian was titled "A Real Transgender Exposing a Fake One." It documents a hijra publicly beating up a transwoman whom she suspects of being a "man." The hijra threatens to "expose" this transwoman by stripping her. She is supported by the bystanders. The transwoman's transgression was that she was begging at the traffic signal. The hijra accused the transwoman of making money while not being transgender. The implication was that "real" transwomen were being shortchanged by "fake" ones. The discourse of "real" and "fake" is not a new one. In the context of hijra communities in south India, Gayatri Reddy writes how a hijra derives izzat (respect) based on whether or not she is asli (real) or nakli (fake). The statuses of asli or nakli are arrived at based on a "performance of various embodied acts, within the arenas of kinship, (a)sexuality, sartoriality, and religion" (Reddy 2005:260). Kinship would include guru-chela (master-disciple) relationships between hijras, religion would mean performance of Islamic rituals and sexuality would mean castration. However, the danger lies in a community-based understanding of gender becoming a national reality through a pan-India law. When a law mandates the formation of a screening committee that will decide if a person is transgender, then ideas of "real" and "fake" receive institutional approval and this approval engenders a lot of violence as depicted in the Logical Indian video. These divisions solidify into identity categories which are then pitted against each other to decide who is eligible for welfare and who is not. Ani Dutta (2013) argues:

Divisions between "real" and "fake" hijras, or more and less feminine kothis, are translated into the distinction between transgender persons and cisgendered (sic) MSM, reifying such divides through institutional discourses of identification ... the attempted formalization of this distinction into an overarching divide between communities tends to elide extant forms of gender/sexual variance between and beyond these specific identities... This especially affects socio-economically marginalized communities like kothis, whose classification as MSM or TG is debated. (P. 498)

There are kothis who do not identify as men but at the same time do not feel trapped in the "wrong body." There are those who do not undergo surgery for a wide range of reasons like lack of funds, health-related issues, or simply because they do not derive their ideas of self solely from their bodies. Each of these gendered expressions are lived realities but a screening committee will only render some of them eligible for state recognition.

The Logical Indian video also signals how the site of gender expression is being used to pit one set of marginalized people against another. What the video showed us was how 
two marginalized people were fighting for their claim to resources that are already scarce. The violence captured in the video is not an isolated incident. Based on personal communication with kothis in my capacity as a volunteer with a transfeminine collective in Kolkata, I have heard of several instances when transfeminine individuals have had their hair cut by so-called "real" hijras. The chopping of hair serves as a warning to "fake" hijras-meaning those kothis who have not undergone castration-to prevent them from soliciting clients in cruising spaces or begging at traffic signals. This is to assert that only "real" hijras have the right to these spaces. Often these physical assaults are audio-visually documented and then disseminated via social media like WhatsApp groups as a warning to other "fake" hijras. Each time such an incident is reported, the justification offered by the assailants is the bogey of authenticity. At a time when the Indian State has been withdrawing itself from its welfare responsibilities such as health, housing and education even as it heightens control on how resources are allocated by way of such eligibility criteria as boards and committees, large swathes of the trans population are being rendered even more economically vulnerable. This results in these fierce gender wars.

17 Even though the Transgender Persons' Bill has been vague about the nature of welfare schemes that transgender people can have access to by simply stating in Section 9(2) of the Bill, "The appropriate Government shall take such measures as may be necessary to protect the rights and interests of the transgender person, and facilitate their access to welfare schemes ..." (Government of India 2018:4), the constitution of screening committees still offers that small window of opportunity for some to gain access to resources and to have such an access, it becomes imperative to ensure that most others fail the screening criterion.

The transgender turf wars have had other violent manifestations as well. Firstly, be it the NALSA verdict or its coverage in the media or the way political parties have spoken about the issue, the categories "transgender" and "hijra" have almost always been deployed interchangeably. Whereas the category "hijra" does not constitute a gender identity, but a specific group of people (which could include transfeminine individuals, kothis and women) with specific religious and linguistic practices, "transgender" serves as an umbrella category for a wide range of people on the gender spectrum who do not identify with the gender they were socialized in. Though the NALSA judgment makes note of the regional specificities of trans* identities (like Hijras, Aravanis, Shiv Shaktis, Jogappas and so on), it mentions transmen and other transmasculine identities only twice in the 150 page ruling (Semmalar 2014). One look at the coverage of the verdict in the mainstream media and it becomes amply clear that the NALSA verdict has been thought of as pertaining to hijras only and to a certain extent, transwomen. Popular media campaigns like the "Bridging the genderation gap!" by Amul ${ }^{9}$ or Seatbelt Crew (VithU 2014), a collaboration between Channel V and the advertising agency, Ogilvy and Mather ${ }^{10}$ perpetuate these elisions engendered by the NALSA verdict. They produce a monolithic identity called "Transgender," who is a hijra by default. When a Supreme Court verdict that recognizes the right to gender expression is reduced to a verdict that recognizes transgender individuals simply as "third gender," then one wonders whether such recognition is easily palatable because the third gender finds space in our Hindu scriptures. Be it at the time of the consultations with the Ministry of Social Justice and Empowerment prior to the NALSA verdict or during the constitution of the 
transgender welfare boards in various states, transmasculine and gender variant people have been totally sidelined.

While screening committees institutionalize violent borders between "real" and "fake" hijras, popular representations of "transgender" only depict hijras. Both these phenomena expose the imbrications of Hindu nationalism with India's transgender movements. This is because, by dint of practicing some Hindu rituals (for example the formation of a kinnar akhada as discussed earlier in the paper) and because of gender expression that can get easily folded into Hindu nationalist ideas of gender, some transfeminine individuals become legible to the state as authentic transgender subjects eligible for citizenship rights. However, such forms of legibility foreclose access to rights and welfare to those transgender individuals who fail to meet these institutionalized criteria and it is mostly the working class, Dalit transwoman or the transman who become illegible to the state.

However, it would be simplistic to argue that hijra subjectivities always reap benefits from their correspondence with Hindu nationalist conceptions of gender. This is because such a relationship gets complicated by the stigma associated with hijra communities on account of their traditional professions, such as begging and blessing newborns. Hence, the constant conflation of "hijra" with "transgender" undergoes backlash in the form of campaigns by upper-caste, upper-class transfeminine individuals who try to distance themselves from the stigma associated with being a hijra. They often try to highlight the fact that, unlike hijras, they are better positioned to have successful careers and therefore they need to distance themselves from the latter. ${ }^{11}$ Jeff Roy (2016) writes that this distancing of transgender from hijra engenders a, "shift from socially transgressive, devalorized modes of hijra social identity toward an embrace of respectable, middle-class transgender ones based on self-understanding and empowerment" (p. 415). So, what we are witnessing is a continuous reification of the very category of gender through which authentic citizen subjects are being produced, who are then to be imbued with rights. What is such reification if not gender policing along the lines of class, caste and the state of the biological body?

21 To understand its dangers, one could also look at the career of screening processes in India's neighboring country, Bangladesh. In November, 2013, the government of Bangladesh officially recognized hijras as the third gender. Earlier in 2011, the parliament of Bangladesh passed a proposal to "rehabilitate" hijras on account of their "disability." Hijras were granted disability allowances. Such measures ultimately culminated in their official recognition as third gender in 2013. One could claim that even though the construction of the hijra identity in Bangladesh as disabled is pathologizing, it could still be a means for them to access welfare from the State. However, a closer investigation of the ramifications of reading non-conforming gender identity as a disability belies such hopes. Adnan Hossain (2017:1418-19) writes how after being selected for the position of office clerk, twelve hijras were forced to undergo a medical examination in 2015. The examination concluded that all twelve of them had male genitalia and therefore were impersonating hijras. Their job offers were immediately rescinded. Yet not all hijras are intersex, many of them do not undergo castration or gender affirmation surgeries. This is a situation that is already playing out in India where different transgender groups are often seen dismissing each other's authenticity by shoring up the specter of gender impersonation (that is the trope of asli and nakli which we discussed earlier in the paper). The constitution of a screening 
committee will only heighten such turf wars because it is obvious that not all transgender subjectivities will pass the test of the screening committees. On the other hand, against the backdrop of khwaja sira ${ }^{12}$ activism in Pakistan, Faris Khan writes that performance of gender ambiguity is a common strategy adopted by them to demand rights in Pakistan. By maintaining an aura of mystery on anatomy and choice of sexual partners, khwaja siras not only conform to the Islamic ethos but also resist prurient interests in their bodies and desires. Hence Khan (2016) writes, "Situated between the poles of normativity and queerness, gender ambiguity offers a form of productive power over mainstream society by preserving the mysterious aura of khwaja siras" (p. 164). What if there were screening committees awarding gender certificates to khwaja siras? The constitution of district level screening committees and the state's pathologized idea of gender will only solidify gender hierarchies further where genderqueer individuals, transmasculine and working-class transgender individuals without any backing from nongovernmental organizations or those who have not gone for surgical transition will be rendered even more vulnerable by medical representatives and community gatekeepers serving on these committees.

In this section, I have attempted to underline the messiness of how the transgender identity is being defined by the state and the impact such a definition has had on transgender communities in India. My attempt has been to show that, even as a Hindu nationalist imaginary of gender allows some transgender individuals to belong to the Indian nation, there are many other gender identities which cannot be part of such an imaginary. I have also tried to show how the very feeling of national belonging is fragile given how discourses of class and respectability disrupt such modes of belonging, as depicted by the campaign against hijras put together by upper class transwomen. In the following section, I take up the site of labor to see how law addresses a fundamental question-any citizen's right to work.

\section{Labor and the transgender citizen}

Most of the media representations of transgender narratives we have discussed so far hinge on the promise of respectability. The Yathartha video portrays transgender women as doctors, engineers, beauticians and police officers, thus distancing the transgender identity from the stigma of sex work and begging at traffic signals. While a proliferation of livelihood options is a desired goal indeed and transgender individuals must be able to choose what careers they will pursue, in reality, there are very few opportunities available for transgender individuals. Even as the state tries to police gender identity by differential allocation of rights, when it comes to the question of labor, the state is near silent. For example, the Transgender Bill states that there should be no discrimination against transgender persons at the workplace. For this purpose, the 2016 version of Bill defined the workplace or establishment as:

Every establishment consisting of one hundred or more persons shall designate a person to be a complaint officer to deal with the complaints relating to violation of the provisions of this Act. (Government of India 2016:4)

The Bill defines establishment as:

(i) any body or authority established by or under a Central Act or a State Act or an authority or a body owned or controlled or aided by the Government or a local authority, or a Government company as defined in section 2 of the Companies Act, 2013, and includes a Department of the Government; or 
(ii) any company or body corporate or association or body of individuals, firm, cooperative or other society, association, trust, agency, institution; (Government of India 2016:2)

By stipulating that an establishment must have a minimum of one hundred employees and that it should be registered with the government, the State made it clear that it is keeping only the small formal economy within its ambit, leaving out the large swathes of the informal economy where most transgender people, primarily from the subordinate castes are employed. Svati P. Shah (2014) defines the informal economy as the "vast segments of national economies that are bureaucratically invisible; this is the untaxed economy, that part of the economy that does not have official governmental oversight but in which everyone participates as producers, consumers, or workers" (p. 9). Be it small factories, domestic work, non brothel-based sex work or beauty parlors-these are all part of the informal economy where many transgender people are employed. The daily harassment faced by them at these work spaces, ranging from low pay, no leisure to sexual harassment are thus rendered invisible because they do not count as discrimination, as the workplace where such discrimination takes place is not even a workplace under Indian law. Yet, these are also spaces which provide them livelihood options within a severely circumscribed field because most establishments turn them away on account of their gender non-conformity. For example, one of the most important options of income generation for transgender women is sex work, coupled with other forms of labor. Shah's (2014) multi-sited ethnographic exploration of sex work in the city of Mumbai shows that it is "one of many livelihood strategies that poor migrants engage in" and is embedded within a "complex discursive matrix that includes life and livelihood histories, the production of urban space, the mutually constituted discourses of caste and gender, and the ways in which economically impoverished migrants navigate the idiosyncrasies of state institutions, from the police to systems of health care" (p. 10). Though Shah conducted her research with female sex workers, such a framework is also relevant for transgender sex workers. Left with almost no option in the formal economy, ${ }^{13}$ often turned out of their natal homes, sex work becomes one of the very few modes of income generation available to them, one that pays for their gender affirmation surgery in the absence of health benefits, pays for housing rent in urban spaces where property prices are soaring and also attends to other basic needs.

Yet the production of a hierarchy of what forms of labor practices are honorable and hence deserve legal protection and what labor practices are not, does not entail newer livelihood options for transgender individuals. It only means pushing them towards further economic precarity. Perhaps, the best way in which this can be proven is this: though the NALSA verdict and later the draft version of the Bill advocated reservations for transgender individuals as Other Backward Classes (OBC) in jobs and educations, ${ }^{14}$ the final version of the bill has totally done away with the provision for reservation stating that $\mathrm{OBC}$ groups objected to including gender and caste categories within the same framework. However, the Indian government has not specified who raised these objections and has not even debated the ramifications of reservation for transgender people. It is also important to note here that the Standing Committee constituted to give feedback on the Transgender Persons' Bill asked the government about harassment at a workplace which has less than 100 employees. The government responded, "It is not practically feasible for small establishments to designate a Complaint Officer. However, 
the mechanism of the police system is robust in India for taking care of such grievances" (Ministry of Social Justice and Empowerment 2016:77). Given that it is often the police who harass, torture and detain transgender women in public spaces, how will the State ensure that the latter can find the most accessible forms of justice from the police? The only concession that the 2018 version of the Bill makes with regard to the definition of "establishment" is that it has removed the stipulation of 100 employees but the rest of the definition remains the same. In other words, the informal economy is still outside the scope of this Bill.

I focused on the question of labor in this section to demonstrate how discourses of nationalism and their connection to transgender citizenship could sometimes lack any material basis. Unlike in the case of screening committees that aim to give an ontological stability to a Hindu nationalist conception of gender that becomes eligible for welfare, the state has made no such concessions when it comes to labor rights for transgender individuals. Thus, nationalist depictions of transgender citizens as successful professionals in the Yathartha video are more for effect than rooted in material realities. In other words, the state effects of the way transgender labor is addressed by Indian law undermine the meta-narrative of the complicities of transgender movements with Hindu nationalism.

\section{Conclusion}

In the previous two sections, I have tried to highlight some of the violent foreclosures engendered by the Indian state's formulation of transgender citizenship. However, foreclosures are also sites of radical possibilities (Dave 2012). For example, even as the Transgender Bill, or the respectability discourse in the media, push out working-class transgender sex workers further to the margins, they continue to find newer ways of eking out livelihoods. A lot of sexual commerce has now moved on to not only newer physical spaces but also to social media. While for some, performing nationalism accords legibility, the lived realities of many others mean a ceaseless battle with the state for better policies, laws and implementation practices. It needs to be underlined here that it was only in the face of country wide protests against the Transgender Bill, where transgender activists burnt copies of the Bill on the streets and conducted protest meetings and marches,$^{15}$ that the central government altered the pathological definition of "transgender" in the Bill. At the time of writing this paper, protest meetings are being conducted across the country against the current version of the Bill. On December 28, 2018, transgender groups from across the country assembled in Delhi to protest against this Bill that was passed by the Lok Sabha. The Bill is currently pending before the Rajya Sabha and in the face of these protests, members of Parliament from the opposition parties have assured transgender activists that they will not allow the Bill to be passed in the Rajya Sabha. However, the Bill did not come up for discussion in the Rajya Sabha and the country goes into general elections soon. Thus, India's transgender communities have successfully stalled the Bill until its next iteration comes up in the Parliament after the elections. Even as the State tries to fix the meaning of gender and everything it can mean, gender as a category and the way it is inflected by class, caste and other specificities continues to disrupt any teleological narrative from chaos to order. The intense contestations around the category of "transgender" proves how even as the state tries to order gender, it fails to do so in the 
face of proliferating oppositional accounts of self making. These oppositional narratives are rooted in complex lived realities that exceed the mandate of law. It is in a careful reading of these excesses that any meta-framework, in this case nationalism, be disrupted.

At the time of writing the conclusion to this paper, Laxmi Narayan Tripathi issued a statement asserting that she supports the construction of a temple in Ayodhya on the land where Babri Masjid stood until it was demolished by Hindu right-wing forces on December 6, 1992 (Verma 2018). ${ }^{16}$ Her statement underlines how Hindu nationalism could be aligned with transgender communities in India. However, this meta-narrative is not the only narrative about transgender movements in India. Tripathi's statement is being severely contested by India's queer and transgender communities. A statement condemning her has been signed by 183 transgender, intersex and gender nonconforming individuals, 20 LGBTQIA+ groups, 8 allied organizations, and 146 individual allies in India. The statement details how the current government has bypassed the NALSA verdict and is criminalizing transgender people through the Transgender Persons Bill and connects such laws with the larger climate of intolerance towards religious minorities in India. Tripathi's vision of a Hindu India for transgender people meets its fiercest challenge in these words from the statement:

Laxmi Narayan Tripathi, a dominant-caste brahmin trans woman, has been appealing to Hindutva ideology and justifying the existence of the caste system in India ever since she began aspiring for a political position within the current ruling party. Her position negates the politics of communal harmony that is espoused by Hijras and Kinnars, who have historically maintained a syncretic faith of belonging to both Hinduism and Islam. Laxmi Narayan Tripathi's position idealises a mythical past of the Sanatan Dharam and supports the right-wing politics of communal hatred in the guise of "we were always accepted." (Sampoorna 2018) ${ }^{17}$

My heartfelt thanks to Saptarshi Mandal for reading multiple drafts of this paper and giving feedback.

\section{BIBLIOGRAPHY}

Bhattacharya, Sayan. 2015. "Board of Mysteries." Kindle, July 1. Retrieved February 12, 2019

(http://kindlemag.in/board-mysteries/).

Chatterjee, Partha. 1993. The Nation and Its Fragments: Colonial and Postcolonial Histories. Princeton and New Jersey: Princeton University Press.

Dave, Naisargi N. 2012. Queer Activism in India: A Story in the Anthropology of Ethics. Durham and London: Duke University Press.

Dutta, Aniruddha. 2013. "Legible Identities and Legitimate Citizens: The Globalization of Transgender and Subjects of HIV-AIDS Prevention in Eastern India." International Feminist Journal of Politics 15(4):494-514.

Dutta, Aniruddha and Raina Roy. 2014. "Decolonizing Transgender in India: Some Reflections." TSQ: Transgender Studies Quarterly 1(3):320-36. 
Foucault, Michel. 1975. Abnormal: Lectures at the Collège de France 1974-75. London and New York: Verso.

Government of India. 2015 “The Rights of Transgender Persons Bill, 2015.” Chennai:Orinam Retrieved February 12, 2019 (http://orinam.net/content/wp-content/uploads/2014/04/ TGBill_2015.pdf).

Government of India. 2016. “The Transgender Persons (Protection of Rights) Bill, 2016.” Chennai: Orinam. Retrieved September 1, 2017 (http://orinam.net/content/wp-content/uploads/2016/08/ TGBill_LS_Eng-1.pdf).

Government of India. 2018. “The Transgender Persons (Protection of Rights) Bill, 2018.” Parliament of the Republic of India. Retrieved February 12, 2019 (http://orinam.net/content/wpcontent/uploads/2018/12/2018_LS_Eng.pdf).

Hossain, Adnan. 2017. "The Paradox of Recognition: Hijra, Third Gender and Sexual Rights in Bangladesh." Culture, Health and Sexuality 19(12):1418-31.

Indian Penal Code. 1860. Section 377 in the Indian Penal Code, "Unnatural Offences." Retrieved April 16, 2019 (https://indiankanoon.org/doc/1836974/).

John, E. Mary. 2009. "Refraining Globalization: Perspectives from the Women's Movement." Economic and Political Weekly 44(10):46-49.

Kakar, Sudhir. 1990. Intimate Relations: Exploring Indian Sexuality. Chicago: University of Chicago Press.

Kaviraj, Sudipta. 1992. “The Imaginary Institution of India.” Pp. 1-39 in Subaltern Studies VIII: Writings on South Asian History and Society, edited by P. Chatterjee and G. Pandey. Delhi: Oxford University Press.

Khan, Faris. 2016. "Khwaja Sira Activism: The Politics of Gender Ambiguity in Pakistan.” TSQ: Transgender Studies Quarterly 3(1-2):158-64.

Mathew, Pheba. 2015. "Viral Video of a Transgender Person Beating-up a 'Fake' Shows How Little We Know About Them." The News Minute, September 23. Retrieved February 12, 2019 (https:// www.thenewsminute.com/article/viral-video-transgender-person-beating\%E2\%80\%98fake\%E2\%80\%99-shows-how-little-we-know-about-them-34571G).

Menon, Nivedita. 2007. “Outing Heteronormativity: Nation, Citizen, Feminist Disruptions.” Pp. 351 in Sexualities, edited by N. Menon. Series editor: R. S. Rajan. New Delhi: Women Unlimited and Kali for Women.

Ministry of Social Justice and Empowerment. 2016. "Standing Committee on Social Justice and Empowerment, The Transgender Persons (Protection of Rights) Bill, 2016, Forty-Third Report. 2017." Chennai: Orinam. Retrieved September 30, 2017 (http://orinam.net/content/wp-content/ uploads/2016/08/StandingCommitteeReport2017.pdf).

NewsClickin. 2017. "Transgender Rights Bill Criminalises the Existence and Livelihoods of Transgender People.” YouTube. Retrieved February 18, 2019 (https://www.youtube.com/watch? $\mathrm{v}=5 \mathrm{USOAbIOGmo}$ ).

Puri, Jyoti. 2016. Sexual States: Governance and the Struggle over the Antisodomy Law in India. Durham and London: Duke University Press.

Reddy, Gayatri. 2005. "Geographies of Contagion: Hijras, Kothis and the Politics of Sexual Marginality in Hyderabad." Anthropology and Medicine 12(3):255-70. 
Roy, Jeff. 2016. “Translating Hijra into Transgender: Performance and Pehchãn in India's TransHijra Communities.” TSQ: Transgender Studies Quarterly 3(3-4):412-32.

Sampoorna. 2018. "Trans, Gender Nonconforming and Intersex Collectives Strongly Condemn Kinnar Akhara's Support for Ram Temple at Ayodhya, India." Retrieved February 12, 2019 (https://sampoornaindiablog.wordpress.com/2018/11/24/trans-gender-nonconformingintersex-collectives-strongly-condemn-kinnar-akharas-support-for-ram-temple-at-ayodhyaindia/?fbclid=IwAR0h_InJV3cQpAPeU5VC9Z6m6fPqABextqWK3RK0a4wnBjTXNFwGKPyy6wI).

Semmalar, Imaan Gee. 2014. "Gender Outlawed: The Supreme Court Judgment on Third Gender and Its implications." Round Table India: For an Informed Ambedkar Age. Retrieved May 15, 2018 (http://roundtableindia.co.in/index.php?option=com_content\&view=article\&id=7377:becausewe-have-a-voice-too-the-supreme-court-judgment-on-third-gender-and-itsimplications\&catid=120:gender\&Itemid=133).

Shah, P. Svati. 2014. "Queering Critiques of Neoliberalism in India: Urbanism and Inequality in the Era of Transnational 'LGBTQ' Rights.” Antipode 47(3):635-51.

Shah, P. Svati. 2014. Street Corner Secrets: Sex, Work, and Migration in the City of Mumbai. Durham and London: Duke University Press.

Singh, Nandita and Nikhil Rampal. 2018. "India's First and Oldest Gay Rights Activist is Also on the Extreme Right of RSS.” The Print, July 21. Retrieved February 11, 2019 (https://theprint.in/ politics/indias-first-and-oldest-gay-activist-uses-a-brand-of-hindutva-to-fight-377/85919/).

Sircar, Oishik and Dipika Jain. 2013. "Neoliberal Modernity and the Ambiguity of its Discontents: Post/Anti-colonial Disruptions of Queer Imperialism." Jindal Global Law Review 4(2):1-22.

The Quint. 2016. “Transgenders Make History with 'Kinnar Akhara' at Kumbh Mela.” YouTube. Retrieved February 11, 2019 (https://www.youtube.com/watch?v=-UiSCODGc6Q).

Transgender India. 2016. “What Does Freedom Mean to You?” YouTube. Retrieved February 12, 2019 (https://www.youtube.com/watch?feature=youtu.be\&v=A3vgcN241Js\&app=desktop).

Upadhyay, Nishant. 2018. “Queer Rights, Section 377, and Decolonizing Sexualities.” Decolonizing Sexualities. Retrieved July 29, 2018 (https://decolonizingsexualities.com/2018/07/).

Verma, Lalmani. 2018. "Kinnar akhara bats for Ram Temple in Ayodhya, Second Term for PM Modi." The Indian Express, November 6. Retrieved February 12, 2019 (https://indianexpress.com/ article/india/kinnar-akhara-bats-for-ram-temple-in-ayodhya-second-term-for-pm-narendramodi-5435495/).

ViTHU. 2014. “Seatbelt Crew" YouTube. Retrieved February 12, 2019 (https://www.youtube.com/ watch?v=muCU6_Y_Kyo).

Yathartha Pictures. 2015. "Bharatiya... Hum bhi hain." YouTube. Retrieved February 11, 2019 (https://www.youtube.com/watch?v=WBRtIxMtGfA).

\section{NOTES}

1. Humsafar Trust is one of India's oldest and most well-funded non-profit groups, working on advocacy programs around HIV-AIDS awareness. Their founder is Ashok Row Kavi, who could arguably be referred to as the Father of India's gay movements, as he gave an interview about his sexuality all the way back in 1986 that encouraged many others to come out. See the video at: https://www.youtube.com/watch?v=WBRtIxMtGfA. 
2. Kinnar is a Sanskrit word that approximately translates as transgender. Akhada is a space for communal living for Hindu celibates, religious leaders and even wrestlers who live and practice together. See Sudhir Kakar (1990) for the inherent homosociality of such spaces. 2016 saw the formation of India's first Kinnar Akhada led by internationally renowned transgender activist, Laxmi Narayan Tripathi. Different akhadas across India congregate on the banks of the river Ganga, considered a Goddess in Hinduism, for a holy bath, symbolizing the ritual cleansing of one's mortal sins. This happens every three years. In 2016, despite much opposition from male dominated akhadas, the transgender akhada participated in the holy bath in an earmarked zone. Thousands of devotees who gathered for bathing paid their respects to the Kinnar Akhada, after the holy bath. For a report on this, see The Quint (2016): https://www.youtube.com/watch?v=UiSCODGc6Q.

3. https://theprint.in/politics/indias-first-and-oldest-gay-activist-uses-a-brand-of-hindutva-tofight-377/85919/

4. The Transgender Person (Protection of Rights) Bill, 2016 can be accessed at: http:// www.prsindia.org/uploads/media/Transgender/Transgender\%20Persons\%20Bill,\%202016.pdf

5. Available at http://orinam.net/content/wp-content/uploads/2014/04/TGBill_2015.pdf

6. The full text of the Bill can be accessed http://orinam.net/content/wp-content/uploads/ 2018/12/2018_LS_Eng.pdf

7. On the lack of transparency in the constitution of the West Bengal Transgender Development Board, see Bhattacharya (2015): http://kindlemag.in/board-mysteries/.

8. See Pheba (2015) on this video.

9. Amul is a cooperative of dairy farmers. They are most noted for their logo of a girl, with a slab of Amul butter. The girl is seen in various places reacting to important news of the day. See Amul's artwork based on the NALSA verdict at https://s3-ap-southeast-1.amazonaws.com/ scrollstorage/1419320789-1045_Amul3.jpg

10. The video of the Seatbelt crew: https://www.youtube.com/watch?v=muCU6_Y_Kyo

11. A non-profit group named Transgender India made this video (2016) featuring five transwomen with established careers and asked them what freedom meant to them. Each of them carried a placard, which had the words "I am not a hijra" written on it. See at https:// www.youtube.com/watch?feature=youtu.be\&v=A3vgcN241Js\&app=desktop

12. Khwaja Sira serves as an umbrella category for various gender and sexuality configurations in Pakistan, including those with congenital genital variations (khunsa), feminine males who cross dress (zennana) and also those zennanas who undergo castration (hijra). Between 2009 and 2012, the Pakistani Supreme Court granted a host of rights to khwaja siras, including the recognition of khwaja sira as a distinct gender category besides male and female. However, when it comes to the daily performance of gender, these categories are not neat.

13. A recent example of how the formal economy does not employ transgender individuals came to light when Air India rejected Shanavi Ponnusamy, a transwoman for the position of female cabin crew. Air India did not cite any reason for this rejection even though Shanavi had met all the eligibility criteria for the job. Even when Shanavi filed a petition with the Supreme Court, Air India did not respond. Finally, having devoted all her resources to the legal battle, Shanavi filed a petition for mercy killing with the President of India. It was then that the Ministry of Civil Aviation asked Air India to respond. Instead of apologizing to Shanavi, Air India threatened to file a case against her for forcing them to give her the job.

14. India's subordinate castes, because of their historical marginalization, are guaranteed reservations in jobs and higher education, in the government sector. The three categories for caste reservation are the Scheduled Castes (SC), Scheduled Tribes (ST) and Other Backward Classes $(\mathrm{OBC})$. The Supreme Court recommended that transgender individuals be granted reservations as OBCs. While the conflation of caste and gender requires further discussion 
because even among transgender individuals, there are many upper castes, the current Bill has foreclosed any further analysis by removing the reservation clause.

15. An audiovisual reportage on the protests against the Transgender Persons Bill by India's transgender movements was made by NewsClickin (2017): https://www.youtube.com/watch? $\mathrm{v}=5$ USOAbIOGmo.

16. https://indianexpress.com/article/india/kinnar-akhara-bats-for-ram-temple-in-ayodhyasecond-term-for-pm-narendra-modi-5435495/

17. https://sampoornaindiablog.wordpress.com/2018/11/24/trans-gender-nonconformingintersex-collectives-strongly-condemn-kinnar-akharas-support-for-ram-temple-at-ayodhyaindia/?fbclid=IwAR0h_InJV3cQpAPeU5VC9Z6m6fPqABextqWK3RK0a4wnBjTXNFwGKPyy6wI

\section{ABSTRACTS}

In a 2014 judgment, the Supreme Court of India affirmed the right of every Indian citizen to choose their gender identity regardless of gender affirmation surgery. Following this judgment, states across India have been constituting transgender welfare boards and the Indian government has approved the Transgender Persons' (Protection of Rights) Bill, 2018 that is supposed to be the one law that will safeguard transgender individuals from any form of discrimination. This legal recognition also coincides with a series of media campaigns that depict transgender individuals staking their claim to Indian citizenship through the trope of nationalism, which is always already majoritarian Hindu nationalism. Thus, these twin developments raise the question of whether performing Hindu nationalism is the only way to claim Indian citizenship. Recent queer studies scholarship from India warns us of the danger of queer and transgender movements getting folded into majoritarian Hindu nationalism, creating constitutive outsides comprised of non-citizens who cannot perform such nationalism. This paper argues that such a meta-narrative risks the danger of missing out on the micro-narratives of resistance and protests emerging from within India's transgender movements that disrupt any singular narrative of transgender individuals performing nationalism to seek citizenship rights.

\section{INDEX}

Keywords: transgender, movements, law, nation, nationalism

\section{AUTHOR}

\section{SAYAN BHATTACHARYA}

GWSS, University of Minnesota 